ACTA VET. BRNO, 55, 1986: 247-261

\title{
thermoregulatory heAt PRODUCtion ' IN LAYING hyBRid hens - SUMMIT METABOLISM
}

\section{NICHELMANN, +'EVA BARANYIOVA and BARBARA TZSCHENTKE}

Sektion Tierproduktion und Veterinärmedizin der Humboldt-Universität zu Berlin, Bereich Physiologie; Sektion Biologie der Humboldt-Universität zu Berlin, Bereich Verhaltenswissenschaften and Department of Physiology, University of Veterinary Science, 61242 Brno

Received January 13, 1986

\section{A b s $\dot{t} r$ a c $t$}

Nichelmann M., Eva Baranyiová, Barbara T z s c h e $\mathrm{n}$ t ke : Thermoregulatory Heat Production in Laying Hybrid Hens - Summit Metabolism. Acta vet. Brno, 55, 1986: 247-261.

Thermoregulatory reactions were studied in 96 laying hybrid hens (age 30 to 35 weeks) under moderate ( 5 to $40 \mathrm{C}$ ambient temperature, $0.2 \mathrm{~m} . \mathrm{s}^{-1}$ air velocity) and extreme environmental conditions ( 5 to $40^{\circ} \mathrm{C}$ ambient temperature, $1.2 \mathrm{~m} . \mathrm{s}^{-i}$ air velocity). Effective ambient temperature (EAT) was calculated from the determined heat production, colonic temperature, evaporative heat loss and conductance. The heat production began to decrease in birds exposed to EAT of -50 to -60 C. At the same time a progressive hypothermia occurred. The summit metabolism was $338 \%$ of the heat production under thermally neutral conditions. Total body thermosensitivity oscillated between 3.1 and 3.7 W. kg $-1 . \mathrm{K}-1$. The increase in colonic temperatyre in the range between thermoneutral temperature (TNT) and $5{ }^{\circ} \mathrm{C}$ in fully feathered birds is in agreement with this, thermosensitivity.

Heat production, feathering, heat loss, effective ambient temperature.

The heat production of homeotherms begins to rise with ambient temperature ( $T_{2}$ ) below the thermoneutral temperature (TNT). In fully feathered sexually mature laying hens the heat production does not exceed $50 \%$ at temperatures between thermoneutrality

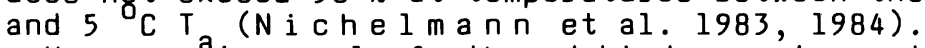

However, in poorly feathered birds, or in partially or totally defeathered ones substantially higher increase in heat production may be expected at the above-mentioned temperatures. Heat production of partially defeathered "Blue Holland" cocks increased by $140 \%$ between 35 and $5 \% \mathrm{C}$ ( $R$ o m i j $\mathrm{m}$ 1950). In laying hens (Babcock 390, brown eggshell) with $65 \%$ of body surface defeathered through mechanical effects during cage rearing an ingrease in heat production by $153 \%$ was observed between 35 and $0{ }_{C}(\mathrm{R} i \mathrm{chards} 1977)$. Light Sussex cocks augmented their 
heat production by $167 \%$ at temperatures between 38 and $22{ }^{\circ} \mathrm{C}$ (0. Neill et al. 1971). Nichel mann et al. (1978) reported on increasing heat production of a parental flock of laying hybrids between TNT and $T$ of $50{ }^{C}$ due to progressive loss of plumage with advancing åge. However, no data are available on the maximum possible thermoregulatory heat production increase in the domestic fowl. Owing to good insulation properties of the plumage it may be expected that the summit metabolism occurs only under extreme thermal conditions.

The question of maximum possible heat production increase in laying hybrids is one of not only theoretical but also practical interest. The domestic fowl is genetically acclimated to high $T_{\text {a }}$ so that a special strategy to combat the adverse effects of low $T$ can be envisaged ( $A$ u I i e and Grav 1978). Moreover, in hens kept under intensive husbandry conditions a combination of poor plumage and high air velocity in the immediate surroundings of the birds may dramatically increase their heat loss and activate their thermoregulatory system.

The $B$ resent paper considers the effects of $T$ between $40{ }^{\circ} \mathrm{C}$ and $5 \mathrm{C}$ on heat production of fully feathered laying hybrid hens as compared to thermoregulatory reactions of birds under extreme cold conditions brought about by complete defeathering and air velocity as high as $1.2 \mathrm{~m} . \mathrm{s}^{-1}$.

\section{Materials and Methods}

Ninety six hybrid laying hens aged 30 to 35 weeks were used. For a period of 4 weeks prior to the experiment the birds were kept on deep litter at a temperature of $20 \pm 1{ }^{\circ} \mathrm{C}$. Commercial food mash and water were available ad libitūm. The photoperiod was $16 \mathrm{~h}$ light throughout.

Four to six days prior to the experiment, 48 birds were defeathered under a Brevinarcon anaesthesia. The flight feathers of the wings and tail were cut off with scissors. The head feathers were not removed. The birds were kept at a temperature of 26 to $28{ }^{\circ} \mathrm{C}$ individually or in pairs until the beginning of the experiment. They were not fasted prior to the procedure.

The hens were individually plaged in metabolism chambers adjustable to temperatures between $5 . \mathrm{C}$ and $40 \mathrm{C}( \pm 0.7 \mathrm{~K})$. Relative humidity in the chambers was 60 to $75 \%$ at temperatures between 15 and $40{ }^{1} C_{C}$; at lower $T_{a}$ it increased to $85 \%$, and the air velo-

The experimental conditions for fully feathered hens were as follows: Ta in metabolism chambers was 5 to $40 \mathrm{C}$, relative humidity 60 to $75 \%$ at $T_{a}$ of 15 to $40{ }^{\circ} \mathrm{C}, 85 \%$ at lower $T_{a}$; air velo-
city $0.2 \mathrm{m.s}$.

Each hen was exposed to the experimental conditions only once for 1 hour. At each $T_{a}$ six birds each of the feathered and defeathered group were investigated.

Immediately prior to the measurements, the body mass and colonic temperature of the birds were determined. After $1 \mathrm{~h}$ exposure to the respective temperatures, the $\mathrm{O}_{2}$ consumption and $\mathrm{CO}_{2}$
production of the birds were measured using a Spirolyt II appa? production of the birds were measured using a Spirolyt II appa-
ratus (VEB Junkalor, Dessau, GDR); the evaporative heat loss was calculated from the water vapour content of the air entering and 
leaving the chambers using psychrometers, and the colonic temperature of the birds was again measured using a fever thermometer. Thermal conductance was calculated from the heat production, evaporative heat loss and colonic temperature. Details concerning the measurements and calculations have been described elsewhere ( $\mathrm{N}$ ichel mann et al. 1973).

Results

Heat production

In feathered hens, the relationship between the $T$ and heat production was expressed in terms of a parabolic function (Fig. 1). The extreme value of the parabola, identical with the thermoneutral temperature, was found at $22.3{ }^{\circ} \mathrm{C}$.

The relationship between $T$ and heat production below TNT was described by the function in ${ }^{a} F i g .2$. This implies that below TNT, the heat production increased by $0.11 \mathrm{~W} . \mathrm{kg}^{-1}$ per $1 \mathrm{~K}$ decrease

in ${ }^{T}$ a ${ }^{\prime}$ feathered hens the heat production of $3.9 \mathrm{~W} . \mathrm{kg}^{-1}$ at $25{ }^{\circ} \mathrm{C}$ increased to $6.3 \mathrm{~W} . \mathrm{kg}^{-1}$ at 5 , rising by $62 \%$.

In defeathered birds the heat production increasedwith falling $T$ at temperatures between 40 and $20{ }^{\circ} \mathrm{C}$ with a minimum $8 f$ $5.4 \mathrm{~W} . \mathrm{kg}^{-1}$ at $40^{\circ} \mathrm{C}$ and a maximum of $13.2 \mathrm{~W} \cdot \mathrm{kg}^{-1}$ at $20^{8} \mathrm{C}$. At lower $T$ their heat production began to fali again. Thus the maximum thermoregulatory increase in heat production of defeathered birds exceeded that of the feathered ones in TNT by $238 \%$.

The relationship between $T_{a}$ and heat production in defeathered birds was expressed in terms of the function given in Fig. 1. The extreme value of the parabola was found at $17.0{ }^{\circ} \mathrm{C}$.

The relationship between $T$ and heat production of these birds at temperatures between 40 and $20{ }^{\circ} \mathrm{C}$ was expressed in terms a $1 \mathrm{i}-$ near function $(y=-0.3220 x+19.260)$. The increase of the curve was with - $0.322 \mathrm{~W} . \mathrm{kg}^{-1}$ three times steeper than the increase of the function foynd in fully feathered hens in the temperature range of 5 and $25 \mathrm{C}$ (Fig. 2 ).

\section{Colonic temperature}

The relationship between $T$ and colonic temperature in fully feathered hens was expressed in terms of a polynomial function $(y=0.0068 x-0.2471 x+43.181 ; r=0.84, n=48, p<8.01)$ given in Fig. 8. The extreme value of this function, $18.8{ }^{\circ} \mathrm{C}$, was identical with the biologically optimal temperature (BOT). Tangents applied to both parts of the parabola intersected at $24 \mathrm{C}$ (Fig. 3). The intersection lay above the extreme value of the parabolic function, being in good agreement with the graphically estimated BOT ( $\left.23{ }^{\circ} \mathrm{C}\right)$.

In defeathered hens the colonic temperature decreased continually with lower $\mathrm{T}$ between 40 and $20^{\circ} \mathrm{C}$ ( $0.11 \mathrm{~K}$ per $1{ }^{8} \mathrm{C} \mathrm{T}_{\text {a }}$ change). This decreasse became 7.5 times steeper $(0.76 \mathrm{~K}$ per 1 C $\mathrm{C}_{\mathrm{T}}$ change) as soon as $\mathrm{T}_{\text {a }}$ was below $20{ }_{\mathrm{C}}$ ( $\mathrm{Fig}$. 9). The equations describing the relationship between $T_{a}$ and colonic temperature of the birds are in Fig. 4 . 


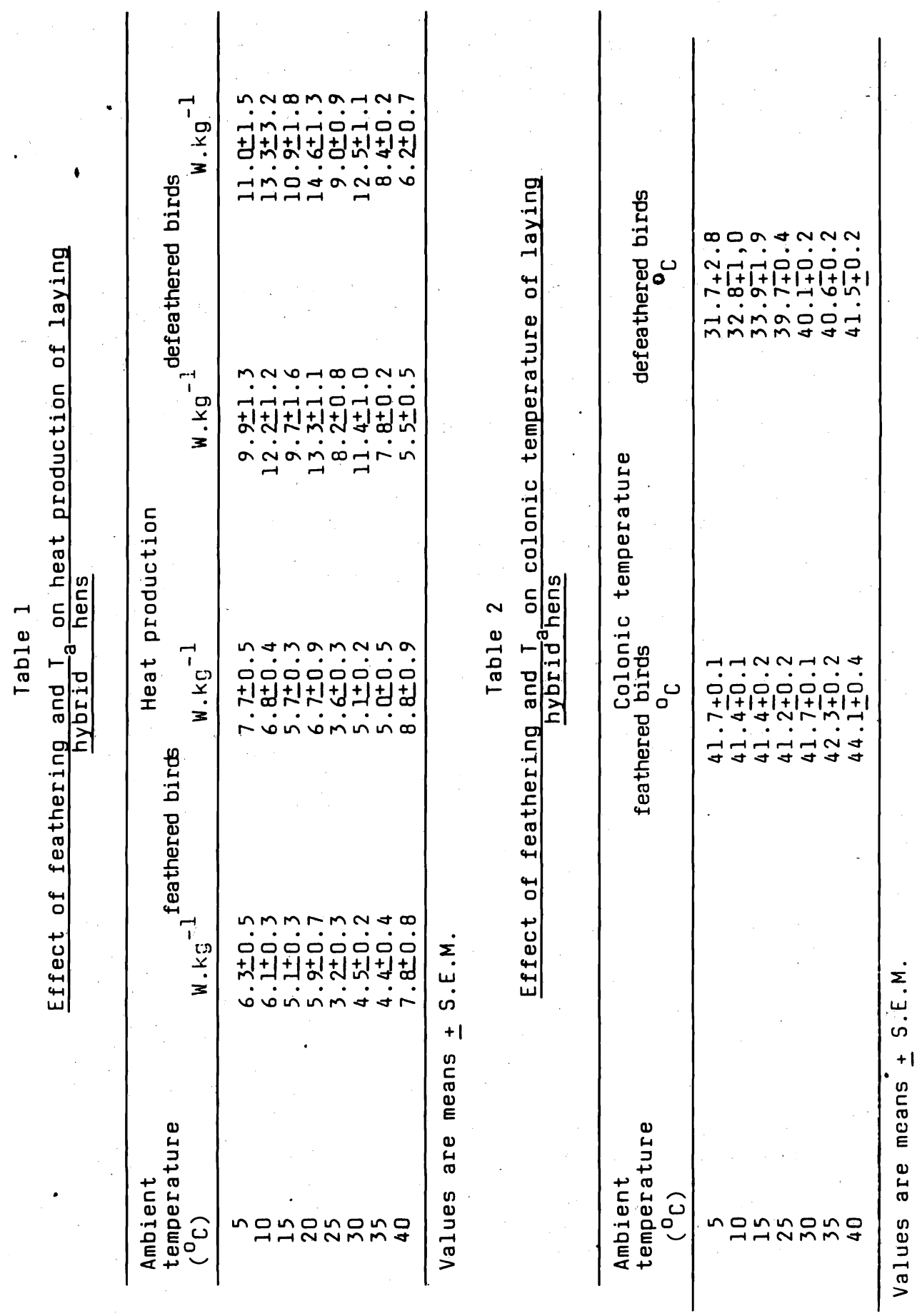




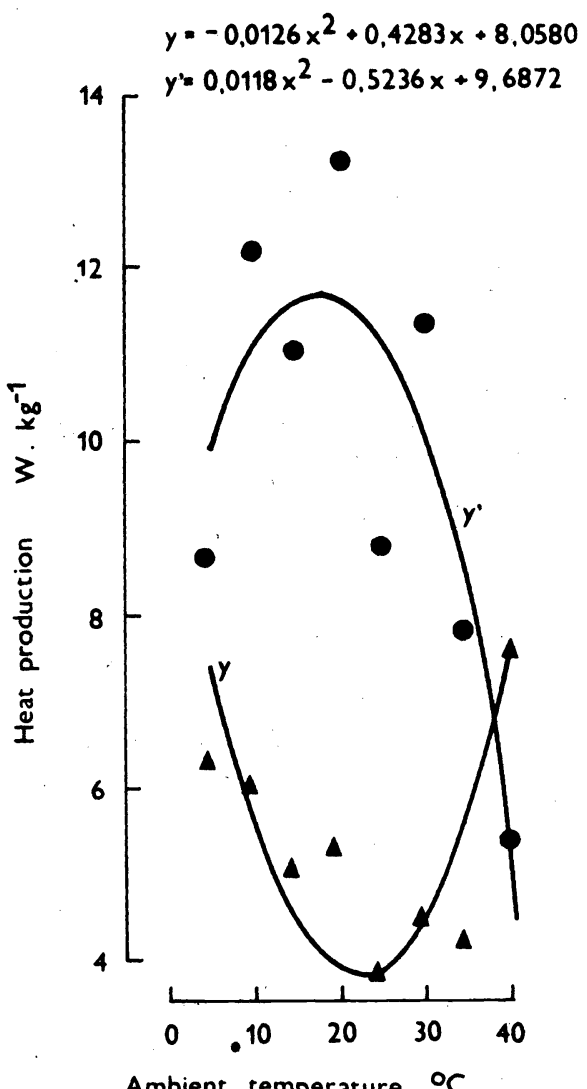

Ambient temperature ${ }^{\circ} \mathrm{C}$

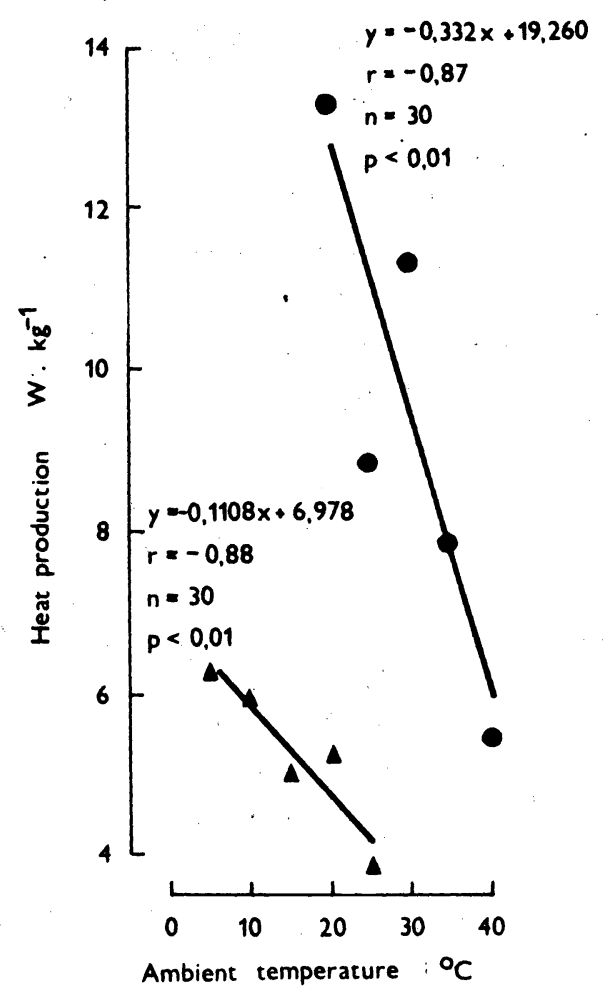

Fig. 1. Relationship between $T_{a}$ and heat production in fully feathered (A) and totally defeathered (•) laying hens

Fig. 2. Relationship between $T_{a}$ and heat production in fully feathered ( $\Delta$ ) hens below. TNT and in defeathered hens ( ) between 20 and $40^{\circ} \mathrm{C}$

The relationship between the colonic temperature and heat production

The incrgase in the colonic temperature in the $T$ range between TNT and $5{ }_{C}$ is explained by the operation mode of the temperature regulating system. Each decline of $T$ results in an elevation of the thermoregulatory set point ( $\mathrm{Ham}$ m e 1 1972). Provided the functioning of the thermoregulatory system is perfect, the increase in colonic temperature below TNT may be used as a measure of the thermoregulatory set point adjustment. The relationship between the colonic temperature and heat production at these temperatures was defined in terms of the function in Fig. 5. Elevation of the curve with 3.3 W. $\mathrm{kg}-1$ indicates that 


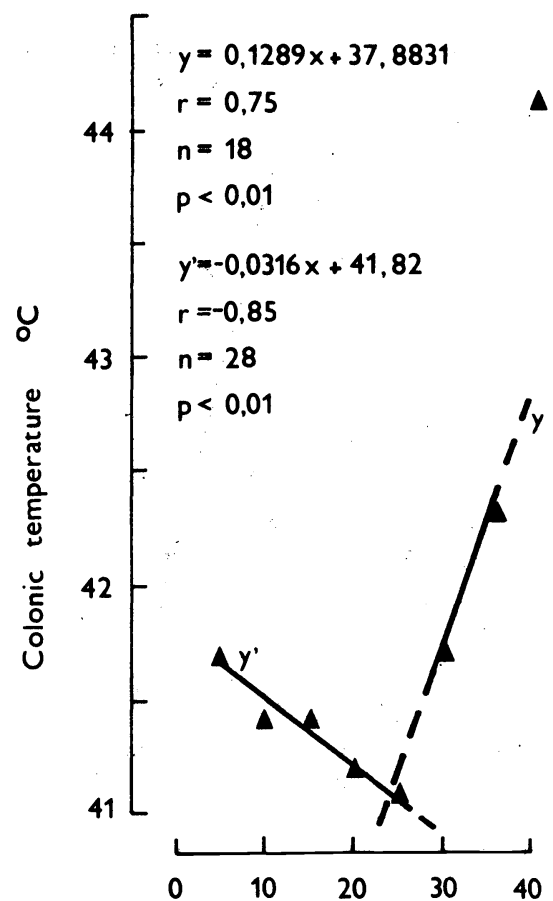

Ambient temperature ${ }^{\circ} \mathrm{C}$

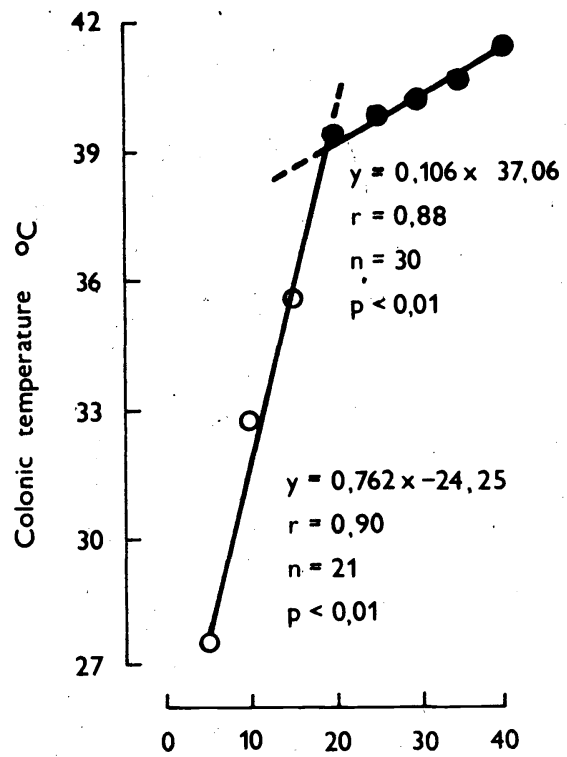

Ambient temperature ${ }^{\circ} \mathrm{C}$
Fig. 3. Linear relationship between $T$ and colonic temperature above and below the biologically optimal temperature in fully feathered hens
Fig. 4. Relationship between $T$ and colonic temperature in at ${ }^{{ }^{a}}{ }_{T}$ between 5 and $20{ }^{\circ} \mathrm{C}$ and between 20 and $40{ }^{\circ} \mathrm{C}$ in defeathered hens

the adjustment of the thermoregulatory set point by 1 K results in an augmentation of heat production by $3.3 \mathrm{~W} . \mathrm{kg}-1$ (Fig. 5).

For an increase of $1 \mathrm{~W} . \mathrm{kg}^{-1}$ in heat production a set point elevation of $0.30 \mathrm{~K}$ was necessary. This was achieved through a decrease in $\mathrm{T}$ by $9.5 \mathrm{~K}$ in fully feathered hens. In defeathered birds, the slight decrease in colonic temperature in $T$ range between 40 and $20{ }^{\circ} C$ was accompanied by a considerable ${ }^{a}$ ise in heat production (Fig. 6). This increase amounted to -3.1 W. $\mathrm{kg}^{-1} \cdot \mathrm{K}^{-1}$ and increased further to $3.7 \mathrm{~W} . \mathrm{kg}^{-1} \cdot \mathrm{K}^{-1}$ provided the data obtained at $25{ }^{\circ} \mathrm{C}$ were not included in calculation. The sharp decline in colonic temperature observed at $T$ below $20{ }_{C}$ led to a remarkable fall in heat production. The resspective equation is given in Fig. 7 . 


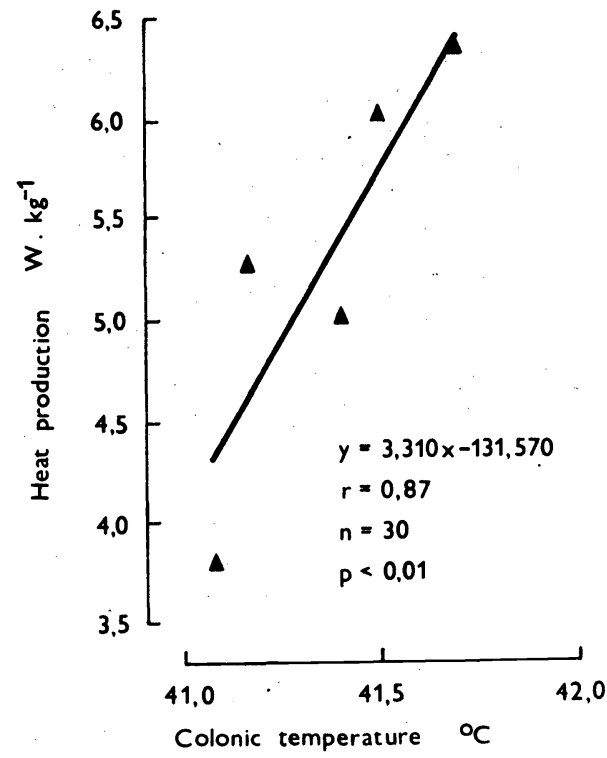

Fig. 5. Relationship between colonic temperature and heat production in defeathered hens at $T$ below the summit metabolism temperature

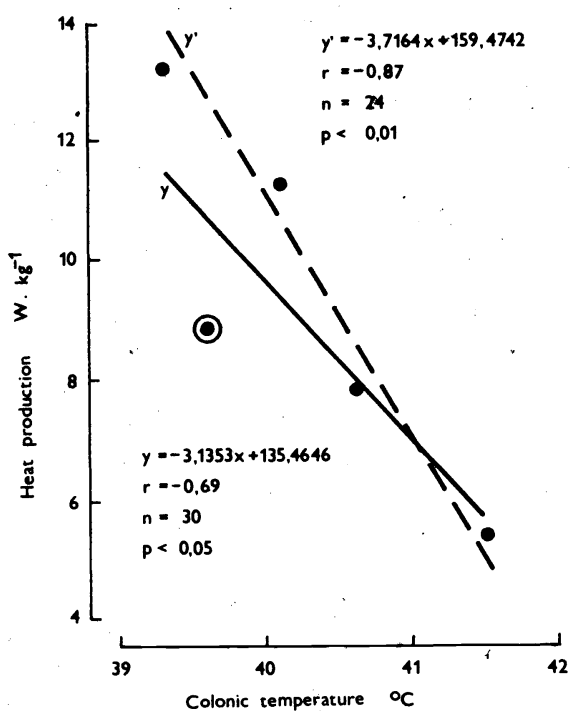

Fig. 6. Relationship between colonic temperature and heat production in defeathered hens at $T$ between 20 and $40{ }^{\circ} \mathrm{C}$ (the curve y does not cover the values obtained at $25^{\circ} \mathrm{C}$ )

\section{Evaporative heat loss}

In feathered hens, the evaporative heat loss was expressed in terms of an exponential function. The evapgrative heat loss began to rise continually above a $T_{\text {of }} 15^{\circ} \mathrm{C}$ and at $40{ }^{\circ} \mathrm{C}$ it amounted to $0.8 \mathrm{~W} \cdot \mathrm{kg}-1$. The threshold temperature for rising evaporative heat loss was $11.3^{\circ} \mathrm{C}$ ( $\mathrm{Fig} .8$ ) as indicated by the course of the straight line expressing the relationship between the $T$ and evaporative heat loss above and below the threshold temperatures.

In defeathered birds, the evaporative heat loss also increased above a T of $15{ }^{\mathrm{C}} \mathrm{C}$. The calculated temperature threshold for these birds was $8.9{ }^{\circ} \mathrm{C}$ (Fig. 9). Analysis of variance revealed. no differences in evaporative heat loss between the two groups of hens.

\section{Thermal conductance}

In feathered birds, the thermal conductance was between 2.1 and $3.2 \mathrm{~W} \cdot \mathrm{m}-2 . \mathrm{K}-1$ in the temperature range between 5 and

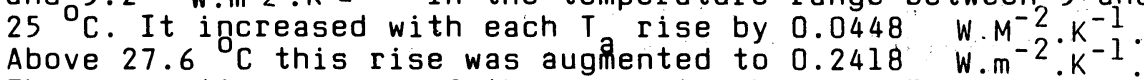
The respective course of the curve is shown in Fig. 8 . 


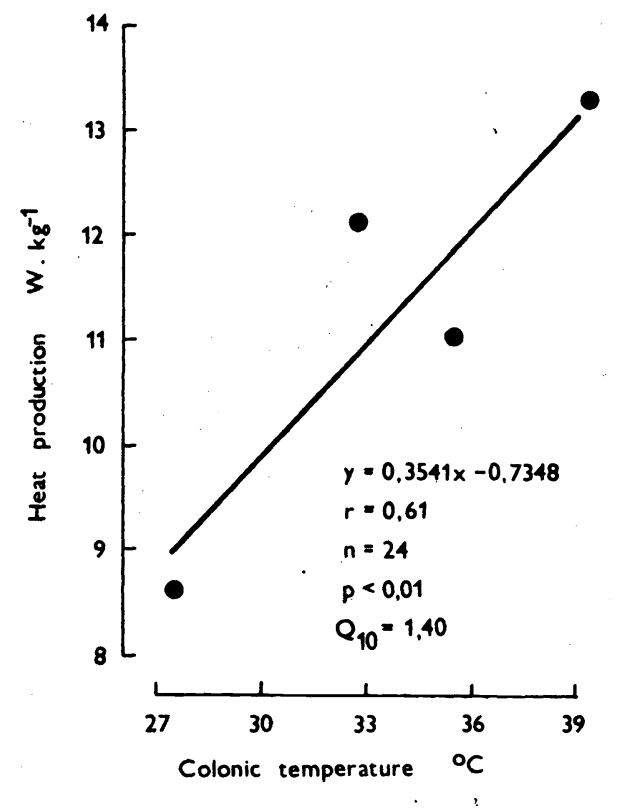

Fig. 7. Relationship between colonic temperature and heat production in defeathered hens at $T_{a}$ between 5 and $20^{\circ} \mathrm{C}$
In contrast, thermal conductance in defeathered birds fell by 0.362 W.m-2 $. K-1$ at temperatures between 5 an $25{ }_{C}$ and rose by

0.470 W.m-2.K-1 at temperatures between 25 and $40{ }^{\circ} \mathrm{C}$ (Fig. 9). Thermal conductance of defeathered hens surpassed considerably that of the feathered birds at each temperature studied.

\section{Discussion}

The relationship between the $T$ and heat production throughout a wide range of $T$ may be expressed in terms of a polynomial function of a higher order (Hense 1 et al. 1973; B ligh 1972) in agreement with generally accepted models based on $G i$ a $j a$ ' $s$ (1938) work. The heat production rises with falling $T$ to a ma$x$ imum - the summit metabolism - at an extremely low $T^{a}$. Below this temperature it begins to decline. The increase $8 f$ the function changes only slightly within the temperature range between just below the TNT and above that of summit metabolism so that this fraction of the polynomial function may be expressed with high significance in terms of a linear function. Indeed, numerous published data indicate such a course of the curve (scholander et al. 1950; Verstegen et al. 1978; Mount 1979).

The actual heat production of a homeotherm is influenced not only by the $T_{\text {a }}$ but also by a variety of thermal and other climatic factors. Particularly important are air humidity, air velocity and thermal radiation as well as factors capable to change the insulation of the animal body. They change the heat output of the animals, and with potent stimulation, also that of internal thermoreceptors. The thus elicited thermoregulatory reaction 


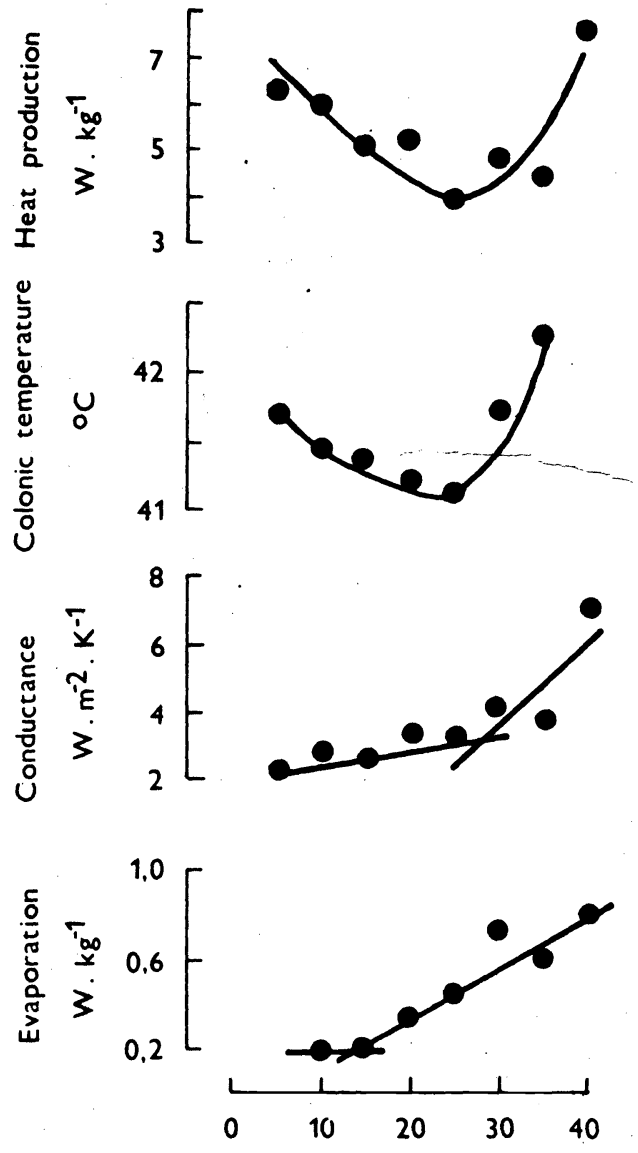

Ambient temperature ${ }^{\circ} \mathrm{C}$
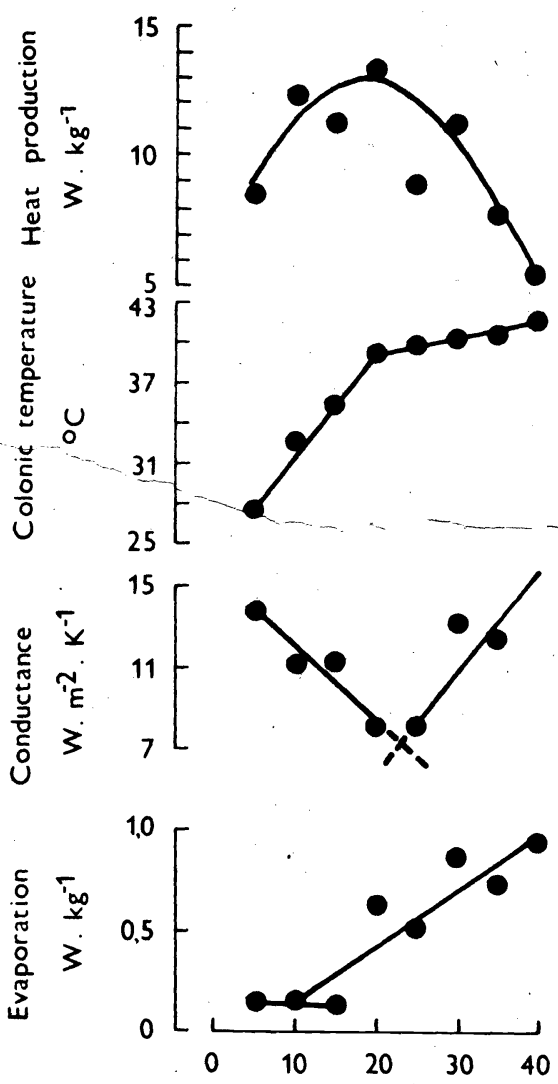

Ambient temperature ${ }^{\circ} \mathrm{C}$

Fig. 8. Relationship between $T$ and evaporative heat loss, thermal conductance, colonic temperature and heat production in fully feathered hens

Fig. 9. Relationship between $T$ and evaporative heat loss, thermal conductance, colonic temperature and heat production in defeathered hens

is a function of thermoregulatory inflow from the population of thermoreceptors in hypothalamic thermoregulatory centre. The route of receptor activation ( $i$. e. changes in a or other above-mentioned factors) is here of no importance.

Environmental factors relevant to thermoregulation have been characterized by the term of effective ambient temperature (EAT) (B I igh and Johns on 1973). According to these authors, all actual environmental situations that result in the same thermal sensations in an individual have the same $T$. As a measure of the EAT in homeothermic animals the thermoregulatory effects of heat production may be employed. This implies - first as a working 


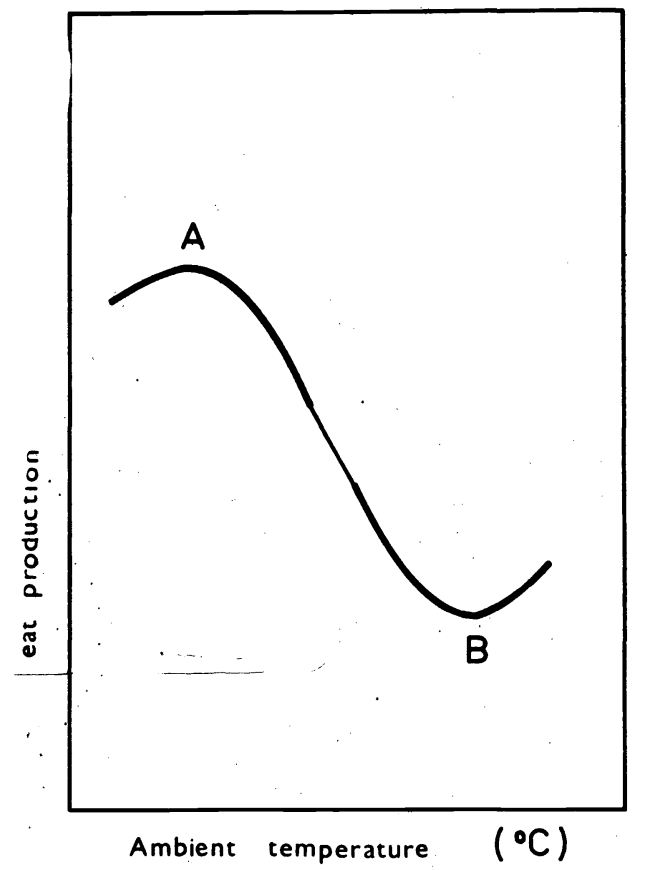

Fig. 10. A schematic presentation of the relationships between $T$ and heat production over a broad temperature range

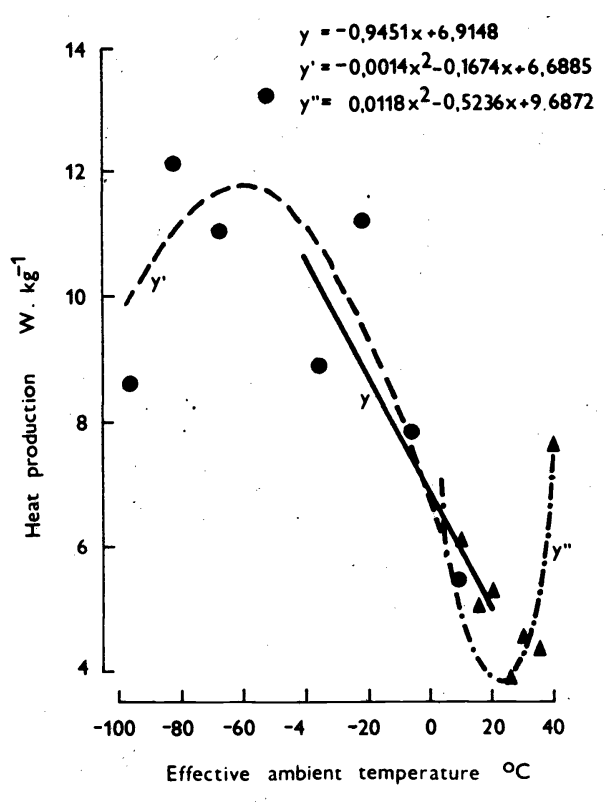

Fig. 11. Relationship between EAT and heat production. The temperature range betweeen -96 and $9{ }^{C}$ is expressed in terms of the function $y$, the temperature range between -36 and $20{ }^{C} \mathrm{in}$ terms of the function $y$, and the temperature range between 5 and 40 . $C$ in terms of the function $y^{\prime \prime}$.

hypothesis - that all environmental factors leading to identical heat production have the same $T$. As a reference, a situation should be employed in which the air velocity would not exceed $0.2 \mathrm{m.s}-1$ and the air humidity would oscillate in a medium range ( 6 oll et al. 1986). Using this concept in interpretation of present results, both parabolic functions expressing the relationship between $T$ and heat production in both groups of hens can be viewed as portions of one curve. A schematic drawing of the relevant conditions is shown in Fig. 10.

The heat production values obtained at low air velocities and with intact feather coat of the birds are plotted in the right part of the curve ( $F i g .10$, part A), the same parameters for the defeathered hens are in the left part (Fig. 10, part B). The courses of the straight lines describing the relationship between $T$ and heat production below TNT in fully feathered birds $\left(-0.1108 \mathrm{~W} . \mathrm{kg}^{-1} \mathrm{l} \cdot \mathrm{K}-\mathrm{I}\right)$ and between $40^{\circ} \mathrm{C}$ and TSM in defeathered hens $\left(-0,332 \mathrm{~W} \cdot \mathrm{kg}^{-1} \cdot \mathrm{K}-1\right)$ differ in their slopes ( $\left.\mathrm{Fig} \cdot 2\right)$. In other words, in hens with removed feathers and exposed to high 
air velocity, one $K$ of $T$ change led to such an increase in heat production that would oflly occur after a $3 \mathrm{~K}$ change in $T$ for fully feathered birds at an air velocity of $0.2 \mathrm{~m}-2 . \mathrm{s}^{-1}$. ${ }^{\text {a Thus }}$ $1.0 \mathrm{~K}$ temperature change under the conditions of increased air velocity and almost total defeathering is equal to $3.0 \mathrm{~K}$ change in the effective ambient temperature. Both functions shown in Fig. 2 indicate that the heat production of defeathered birds at $40{ }^{\circ} \mathrm{C}$ is equal to that of fully. feathered ones at $9{ }^{\circ} \mathrm{C}$. This finding along with that of a $1: 3$ ratio in the effect of temperature change upon the heat production of feathered and defeathered birds provide a basis for calculation of the EAT summarized in Table 3 . The course of the curve constructed on the basis of these data and showing the relationship between Ta and heat production, is shown in Fig. 11. The TSM of laying hens lay at an EAT of -50 to $-60^{\circ} \mathrm{C}$.

In the present experiment, the heat production of hens at TSM attained $338 \%$ of its value found at TNT. This thermoregulatory increase in heat production is somewhat lower than the values found by Alexander and Willi ams (1968) in newborn lambs (i. e. 430\%) and in older lambs (540\%). In Pekin ducks a fivefold increase in heat production was elicited by whole-body cooling through intraintestinal thermodes ( $\mathrm{nomoto}$ and $\mathrm{Si}$ mo n 1981).

Table 3

Actual ambient temperature $T$ and effective ambient temperature (EAT) in fully feathered ard defeathered laying hybrid hens

\begin{tabular}{|c|c|c|c|c|}
\hline \multicolumn{2}{|c|}{$\begin{array}{l}\text { Featnered } \\
\text { birds } \\
\text { Air velocity } \\
0.2 \mathrm{~m} \text {. s }\end{array}$} & \multicolumn{3}{|c|}{$\begin{array}{l}\text { Defeathered } \\
\text { birds } \\
\text { Air velocity } \\
1.2 \mathrm{~m} \text {. s }\end{array}$} \\
\hline $\mathrm{T}_{\mathrm{a}}\left({ }^{\mathrm{O}} \mathrm{C}\right)$ & EAT $\left({ }^{\circ} \mathrm{C}\right)$ & $\mathrm{T}_{\mathrm{a}}$ & $\left({ }^{0} \mathrm{C}\right)$ & EAT $\left({ }^{\circ} \mathrm{C}\right)$ \\
\hline $\begin{array}{l}5 \\
10 \\
15 \\
20 \\
25 \\
30 \\
35 \\
40\end{array}$ & $\begin{array}{l}5 \\
10 \\
15 \\
20 \\
25 \\
30 \\
35 \\
40\end{array}$ & $\begin{array}{r}5 \\
10 \\
15 \\
20 \\
25 \\
30 \\
35 \\
40\end{array}$ & & $\begin{array}{l}-96 \\
-81 \\
-96 \\
-51 \\
-36 \\
-21 \\
-\quad 6 \\
+\quad 9\end{array}$ \\
\hline
\end{tabular}

The increase in heat production observed in our study was relatively low compared with that occurring during an intensive muscular activity. Birds with the body size range similar to that of the domestic fowl are capable to augment their heat production 10 times during flight or running on a treadmill. The $0_{2}$ consumption of resting domestic fowl ( $2.48 \mathrm{~kg}$ body mass) at $\mathrm{TNT}^{2}$ amounted 
to $9.5 \mathrm{ml} . \mathrm{kg}^{-1} \cdot \mathrm{min}^{-1}$, whereas during a run of $9 \mathrm{~km} \cdot \mathrm{h}^{-1}$ it increased to 112.5 to $115.0 \mathrm{ml} . \mathrm{kg}^{-1} . \mathrm{min}^{-1}$ (B r a ckenbury and $A v e r y$ 1980). No explanation for the differences in the maximum possible increase in heat production during a thermoregulatory reaction at low $T$ and during a maximu muscular activity (running, flying) can be offered.

In the present study, a continuous fall in colonic temperature was observed in defeathered hens at T declining from 40 to $20{ }^{\circ} \mathrm{C}$. This fall was accompanied by a considerable increase in heat production of 3.1 to $3.7 \mathrm{~W} . \mathrm{kg}-1$ per $\mathrm{K}$ of $\mathrm{T}$ change. This change in heat production can be employed as a meâsure of thermosensitivity of the thermoregulatory system assuming that the temperature change is equal in all receptor fields. Whole body thermosensitivity of 5 to $6 \mathrm{~W} \cdot \mathrm{kg}^{-1}$ at low and medium T was determined in Pekin ducks with core temperature decreased by an intestinal thermode, and body thermosensitivity of $3.2 \mathrm{~W} . \mathrm{kg}-1$ at high $\mathrm{T}_{\mathrm{a}}$ ( I n o mot o and $\mathrm{S}$ i m on 1981).

The relatively low thermosensitivity of our experimental birds as compared to other species may lay in different experimental methods employed as well as in species differences in receptor thermosensitivities.

Our observations on elevated heat production in feathered birds between TNT and $5{ }^{\circ} \mathrm{C}$ accompanied by a simultaneous increase in colonic temperature suggest a rather low thermosensitivity of the temperature regulation system in domestic fowl. This phenomenon may be connected with a thermoregulatory set point adjustment at

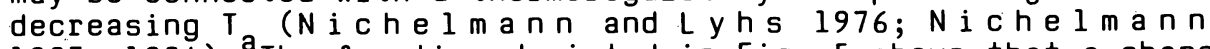
$1983 ; 1984)$. The function depicted in Fig. 5 shows that a change in thermoregulatory set point by $1 \mathrm{~K}$ results in an increase in heat production of $3.3 \mathrm{~W} \cdot \mathrm{kg}^{-1}$. This value is in good agreement with the whole body thermosensitivity of 3.1 to $3.7 \mathrm{~W} . \mathrm{kg}-1$ determined in our experimental birds.

Below the EAT of -50 to $-60{ }^{\circ} \mathrm{C}$ the colonic temperature of defeathered hens began to drop sharply. At the same time their heat production decreased, leading in turn to further colonic temperature decline. For the effect of temperature a $Q_{1}$ of 1.4 was calculated ( $\mathrm{C}$ a $\mathrm{l} \mathrm{de} \mathrm{r}$ and $\mathrm{K}$ ing 1974). Assuming that in a living organism a $Q$ of 2.0 expresses the effect of a temperature change on biochemical reaction rates, a $Q$ value of 1.4 means that in domestic fowl with a colonic temperature lower than $39.5{ }^{\circ}$ the heat production is indeed decreased through local effect of temperature on metabolically active cells but that efferent effects from the thermoregulatory centre are still in operation to prevent this decrease.

The control elements of the thermoregulatory system activated in a typical sequence in fully feathered hens ( $\mathrm{N}$ i che $1 \mathrm{~m}$ a $\mathrm{n} \mathrm{n}$

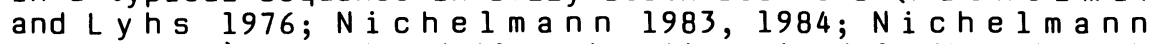
et al. 1985) showed a different pattern in defeathered birds (Fig. 9). Of interest is the relationship between the maximum heat productions of fully feathered birds at $20{ }^{\circ} \mathrm{C}\left(3.9 \mathrm{~W} . \mathrm{kg}^{-1}\right)$ and the defeathered ones at $40 \mathrm{C}\left(5.4 \mathrm{~W} . \mathrm{kg}^{-1}\right)$ : both temperatures are thermoneutral for the respective groups of birds. The heat production of defeathered birds was still substantially higher due to their high radiation heat loss. 
Both the evaporative heat loss and thermal conductance began to increase at an ambient temperature at which the organism of the bird was exposed to a considerable thermal load. The heat loss was thus enhanced at a temperature at which hypothermia occurs. The reasons for this seemingly paradoxical reaction are not understood and require further study.

\section{Termoregulačni produkce tepla u hybridnich nosnic}

U nosnic hybridủ ve věku 35 až 40 týdnů byly sledovány termoregulační reakce při mírné ( 5 - $40{ }^{\circ} \mathrm{C}$ teplota prostredí a 0,2 M. $s^{-1}$ rychlost prouděni vzduchu) a při extrémní ( 5 - 40. C teplota prostredí a $1,2 \mathrm{~m} . \mathrm{s}-1$ rychlost proudění vzduchu) teplotni zátěži. Z naměrených hodnot energetického metabolismu, teploty $v$ kolonu, evaporačnich ztrát tepla byla vypočtena efektivni teplota prostředi. Energetický metabolismus nosnis počal klesat při efektivní teploté prostředí -50 až $-60{ }^{0} \mathrm{C}$ a zároveñ nastoupila progresivní hypotermie. Energetický metabolismus za těchto podmínek prevyšoval o 338 \% jeho hodnoty naměrené $v$ termoneutrálním prostredí. Termosensitivita termoregulačníno systému se pohybovala mezi 3,1 a $3,7 \mathrm{k} \cdot \mathrm{kg}^{-1}$. K-l. Tato termosensitivita dostatečně vysvětluje vzestup teploty těla nosnic v rozmezí termoneutrální teploty prostredí a 5 C.

\section{Терморегуляторная теплопродукция у гибридных несушех}

у несушех гибридов в возрасте 35 - 40 недель проводили наблюдения за терморегуляторными реахциями при умеренной $\left(5-40^{\circ} \mathrm{C}\right.$ температура охружаюшей яреды и $0,2 \mathrm{M.山}-1$ скорость воздушного течения)

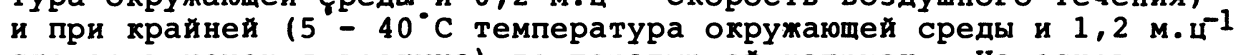
скорость течения воздуха) температурной нагрузке. На основе полученных величин метаболизма энергии, температуры в ободочной кишке и температурных потерь выпариванием, была вычислена еффективная температура охружаютей среды. Метаболизм энергии несушех стал понижаться при еффехтивной температуре охружающей среды $-50--60^{\circ} \mathrm{C}$ и одновременно проявилась прогрессивная гипотермия. Энергетический метаболизм в данных условиях превышал на 3388 величины, полученные в термонейтральной среде. Термочувствительность терморегуляторной системы достигала пределов 3,1 и 3,7 Вт. $\mathrm{K}^{-1} \cdot \mathrm{K}^{-1}$. Приведенная термочувствительность в достаточной степени объясняет увеличение температуры тела несушех в пределах термонейральных температурных величин охружающей среды и $5^{\circ} \mathrm{C}$. 
ALEXANDER, G. - WILLIAMS, D.: Shivering and non-shivering thermogenesis during summit metabolism in young lambs. J. Physiol., London, 198, 1962: 251 - 276.

AULIE, A. - GRAV, H. J.: Effect of cold acclimation on the oxidative capacity of skeletal muscles and liver in young bantam chicks. Comp. Biochem. Physiol., 62A, 1978: 335 - 338 .

BLIGH, J.: Temperature regulation in mammals and other vertebrates. Academic Press, London and New York, 1973.

BLIGH, J. - JOHNSON, D.: Glossary of terms of thermal physiology. J. appl. Physiol., 35, 1973: 941 - 961 .

BRACKENBURY, J. H. - AVERY, P.: Energy consumption and ventilatory mechanisms in the exercising fowl. Comp. Biochem. Physiol., 66A, 1980: $439-445$.

CALDER, W. A. - KING, J. R.: Thermal and caloric relations of birds. In: FARNER, D. S. - KING, J. R. (Editors): Avian Biology, Academic Press, New York and London, 1974, vol. IV, pp. 259 - 413.

FREEMAN, B. M.: Some responses of the domestic fowl to environmental temperature. Arch. exper. Vet. Med., 38, 1984 : $392-398$.

GIAJA, J.: L homeothermie. Paris, 1938: $180 \div 185$.

GOLL, R. - NICHELMANN, M. - TZSCHENTKE, B.: Thermoregulatorische Wärmeproduktion bei Legehybriden - Einfluss der effektiven Umgebungstemperatur. Arch. exper. Vet. Med., 40, 1986: 000 - 000 .

HAMMEL, H. T.: The set-point in temperature regulation: analogy or reality. In: BLIGH, J. - MOORE, R. (editors), Essays on temperature regulation. North Holland Publ. Company, Amsterdam - London, 1972: 121 - 137.

HENSEL, H.' - BRUCK, K. - RATHS, P.: Homeothermic organisms. In: PRECHT, J. - CHRISTOPHERSON, J. - HENSEL, H. - LARCKER, W. (editors). Temperature and iffe. Berlin, Springer Verlag, 1973.

INOMOTO, T. - SIMON, E.: Extracerebral deep-body sensitivity in the pekin duck. Am. J. Physiol., 241, 1981: R 136 - R 145 .

MOUNT, L. E.: Adaptation to thermal environment; man and his productive animals. Edward Arnold, London, 1979.

NICHELMANN, M.: Some characteristics of the biological optimum temperature. J. Therm. Biol., 8, 1983: 69-71.

NICHELMANN, M.: Das Konzept von der biologisch optimalen Temperatur. Arch. exper. Vet. Med., 38, 1984: $419-430$.

NICHELMANN, M. - LYHS, L.: Zur Bestimmung der biologisch optimalen Temperatur. Mh. Vet. Med., 31, 1976: 546 - 554.

NICHELMANN, M. - ROTT, M. - ROHLING, H.: Eine Methode zur Untersuchung des Wärmehaushaltes nichtwiederkäuender landwirtschaftlicher Nutztiere. Arch: exper. Vet. Med., 27, 1973: 514 - 525 .

NICHELMANN, M. - OESER, B. - LADEMANN, H. - GROSSKOPF, C . : Der Einfluss des Befiederungsgrades auf den Wärmehaushait von Legehennen. In: Die Wirkung von Umweltfaktoren auf die Leistungsfähigkeit landwirtschaftlicher Nutztiere und ihre steuerung zur Beeinflussung des Anpassungsvermögens mit dem $\mathrm{Ziel}$ der Leistungssteigerung. Karl-Marx Universität; Leipzig, 1978.

NICHELMANN, M. - HEWALD, B. - GRUNE, B.: Thermoregulatorische Wärmeproduktion bei Legehybriden - Beziehungen zwischen Lebensalter und Wärmeproduktion. Arch. exper. Vet. Med., 37, 1983: $341-352$. 
NICHELMANN, M. - NELTE, B. - El SHAARRAWI, G.: Zur biologisch optimalen Temperatur von Legehybriden - Beeinflussung durch das Alter. Arch. exper. Vet. Med., 39, 1985a: 166-182.

NICHELMANN, M. - EL SHAARAWI, G. - NELTE, B.: Thermoregulatorische Wärmeproduktion bei Legehybriden - Beziehungen zwischen Wärmeproduktion, evaporativer Wärmeabgabe und Wärmedurchgang durch die Körperschale. Arch. exper. Vet. Med., 39, 1985b: 136-155.

O'NEILL, S. J. B. - BALNAVE, D. - JACKSON, N.: The influence of feathering and environmental temperature on the heat production and efficiency of utilization and metabolizable energy by the mature cockerel. J. agric. Sci., 77, 1971: 293 - 305.

RICHARDS, S. A.: The influence of loss of plumage on temperature regulation in laying hens. J. agric. Sci., 89, 1977: $393-398$.

ROMIJN, C.: Stoffwisselingsonderzoek big de kip. Tschr. Diergenessk., 75, 1950: $839-856$.

SCHOLANDER, P. F. - WALTERS, V. - HOCK, R. - IRVING, L.: Body insulation of some arctic and tropical mammals and birds. Biol. Bull., 99, 1950: 225 - 236 .

VERSTEGEN, M. W. A. - BRASCAMP, E. W. - VAN DER HEL, W.: Growing and fattening of pigs in relation to temperature of housing and feeding level. Can. J. Sci., 58, 1978: 1 - 13 .

VAN KAMPEN, M.: Physiological responses of poultry to ambient temperature. Arch. exper. Vet. med., 38, 1984: 384 - 391.

TULLETT, S. G. - MACLEOD, M. G. - JEWITT, T. R.: The effects of partial defeathering on energy metabolism in the laying fowl. Br. Poult. Sci., 21, 1980: 241 - 245.

TZSCHENTKE, B. - NICHELMANN, M.: Beeinflussung der biologisch optimalen Temperatur von Legehybriden durch die Luf tgeschwindigkeit. Arch. exper. Vet. med., 38, 1984: $319-326$. 